\title{
STRUGGLE AGAINST HEGEMONY IN THE ADVENTURES OF HUCKLEBERRY FINN AND THE KITE RUNNER
}

\author{
Alfi Muhammad Firdaus ${ }^{1}$ and Mahi M. Hkikmat ${ }^{2}$ \\ UIN Sunan Gunung Djati ${ }^{1}$, Bandung, fhimuhammd@gmail.com \\ UIN Sunan Gunung Djati ${ }^{2}$, Bandung, mahimhkikmat@uinsgd.ac.id
}

\begin{abstract}
Novels The Adventures of Huckleberry Finn written by Mark Twain and The Kite Runner written by Khaled Hosseini have similarities in describing struggle against hegemony. The term of "hegemony" is related to a domination of dominant group to subordinate group through agreement. In addition, this hegemony can also include physical violence to strengthen the domination. Meanwhile the term "Struggle" means that there are also resistances against the hegemony. These two novels were analyzed by comparative literature theory by Susan Basnett and Antoni Gramsci's theory about hegemony. Focus of this research is how the writers describe hegemony and counter hegemony in social environment through literary work. This research aims to describe hegemony from dominant group to subordinate group in several kinds such as culture, ideology, intellectual and moral leadership, and state. This research also describes about several resistances, such as active, passive, and humanistic resistance. The result of this research is that there are similarities and differences of hegemony and counter hegemony based on state of factor of American and Afghanistan. The similarities can be found in the struggle, such as passive and humanistic resistance. Meanwhile for the difference in hegemony, the novel The Kite Runner includes physical hegemony through war and assassination. For the difference in struggle, The Kite Runner provide an active resistance toward a dominant group.
\end{abstract}

Keywords: Hegemony; Counter Hegemony; Comparative Literature

\section{INTRODUCTION}

This topic of this paper about struggle against hegemony is described in two novels, namely, novel The Adventures of Huckleberry Finn and The Kite Runner. Novel The Adventures of Huckleberry Finn (1884) is an American literary work which presents a portrayal of boyhood and social condition in America (Britannica, 2019). Social condition in America portrays about domination of white people toward black people. It is written by Mark Twain and published for the first time in 1884s in England and then in 1885s in America. Meanwhile novel The Kite Runner (2003) is written by Khaled Hosseini which is published in 2003s, America. It portrays about domination of Pashtun towards Haza. From those two works can also be figured out a same portrayal of socail condition such as hegemony and counter hegemony. In the message which is conveyed by the writers, those two novels are written in style of adventure and struggle for life based on children friendship.

Furthermore, hegemony is a type of leadership after domination. Hegemony is caused by the effort from the ruler to enlarge his authority and domination through society. This is happened because domination only creates a stability and 
safety above people's suffering. Then, domination can't occur continuously because ordinary people can't make any resistance for it because of lack of the power. And hegemony as a second type of supremacy leads a group not only for domination or oppression but also moral and intellectual leadership (Hendarto, 1993). Because this leadership type creates such a negotiation that make an intellectual and moral approval on social and political order. Consensus is an important part of hegemony because it is an alternative for dominating and controlling, instead of oppressing other social class. Gramsci added in (Suyitno, 2014), hegemony is a construct for domination where a ruler class use its social and leadership authority against lower class with a combination between unaware and aware consensus. For example, hegemony directly or indirectly goes into the cognitive structures of the society. So, hegemony drives people to view and value social problems in the determined framework.

\section{LITERATURE REVIEW}

Literature is a media for the writer to express his experience and view about social condition through language. It means that the writer creates a literary work based on a social condition and represent it with a new world. The writer tries to describe a reality by his creative idea on works as the view of some problems happened in the time and place, he lived. A relationship between literary work and reality comes because literary work was born from the idea owned by writer when he has encountered phenomena or realities (Abrams, 1976). For instance, the social problem manifested in conflict, racism, and slavery is caused by hegemony of social group. Thus, the hegemony problem itself have to be solved around the social community in order to make a good social order and remove discrimination between people.

The story from people presents an actual condition after colonialism phase. The creation of new state or country cannot be separated by leadership and authorization to make the rule and also social arrangement. Then, some problems come from them who want to take that position as a leader and make them as a high social class. The effect from this is the existence of subordinate class who have a discomfort of their life. Injustice becomes clear when the ruler class make the regulation which don't appropriate a multi ethnic or race environment.

Besides that, this power become stronger when the ruler class imply the purpose of their power by leadership through a hegemony. So, if the colonialism gets their leadership by many oppressions or violence to dominate people, hegemony has reached a schematic version of the domination. The power of leadership goes through in social aspects such as culture, ideology, intellectual and moral. Even though there is still a practice that is supported by state law and enforcement. There are some novels portray about this condition especially in a dilemmatic version of the writer to respond about the actual condition around his life. The description of the struggle as an opposition to a conservative view often emerges in literary work. The idea conveyed in literature provides some ways to get a human's freedom inside the injustice through the hegemony in social reality.

The concept of hegemony is subdivided to four elements (Yusuf, 2017):

1. Culture, means a material power that has a significant effect for society.

2. Ideology, means an idea system that is based on the way of human's life in a particular period and place. 
3. Intellectual moral and leadership, means those who organize the community in the social environment.

4. State, means the integration between civil society and political society.

To resist that hegemony, two writers show the struggle against hegemony. It means that the struggle refers to how the people deny all kinds of hegemony that happens around them. This struggle includes the opposite idea towards dominant idea that is supported by society's approval. Besides that, the struggle needs a support from other institutions inside society to create and maintain alliance system in the political and ideological contest. To bring out this counter, the people should use their consciousness of their subordination. According to Patria in (Wiharjo, 2018), Gramsci states that consciousness is an important thing to arise struggle against dominant class. In order to make revolution existed, the society should take an action. But before that happen, they should know about the essence and situation of their existence in the system that is being lived.

In the literary work, the struggle can be manifested in various ways based on the historical context of behavioral, background, and the motive of characters. That struggle may be appropriated with the consciousness from each character that they should encounter the dominant class. According to (Wiharjo, 2018) There are three types of this struggle;

1. Active resistance, means the resistance is related to the act of resistance with a confrontation towards the ruling class and an attitude or action that is not appropriated with the ruling class' desire.

2. Passive resistance, means not to do the mainstream's desire or do a negative thing which can be a self-harm as a form of protest against that mainstream domination of hegemony.

3. Humanistic Resistance, an alternative contemplation for people to value whether the hegemony is right or wrong.

\section{METHOD}

According to (Creswell, 2014),research design gives a specific direction for the researchers in the process of inquiry in quantitative, qualitative, and mixed methods. Then, this research is a qualitative research which uses descriptive analysis method. It means that the researcher will use this qualitative method to describe the facts of the data and analyze them (Ratna, 2006). In other hands, this research will not use the form of numerical figures, but the form of descriptions. Cresswell continued in , (Azizah, 2019) qualitative methods relate to certain process of studying and understanding a social and humanity problem, based on words conducted in a natural setting that can make a picture and detailed views that are conveyed by informants. This research uses a source of main data from the first novel book entitled The Adventures of Huckleberry Finn which is published by Gramedia Pustaka Utama in Jakarta, in 2018. This book of novel contains 434 pages in 43 chapters. Then, the second book novel is entitled The Kite Runner which is published by Bloomsbury Publishing in London in 2007. This book contains 324 pages with 25 chapters. The primary data of this research is element of hegemony includes culture, ideology, intellectual and moral leadership, and state. Beside that the researcher also take the kind of counter hegemony such as 
active, passive, and humanistic resistance as primary data. Furthermore, other informations from web, article, and news are used as secondary data.

With that method, the researcher intends to find the historical contexts of each novel based on some expressions or dialogues from characters that lead to the main topic. So, it can be figured out the influence of literary work which can be a media for society for conveying their ideas about social problem. Especially in the place, where the domination will be larger if hegemony is carried out by ruler. And in this case, literature can be a new idea or a counter of hegemony which protects the rights of subaltern.

\section{FINDINGS AND DISCUSSIONS}

There are similarities and differences in the novel The Adventures of Huckleberry Finn and The Kite Runner related to the main topic of hegemony and counter hegemony.

\section{Similarities Hegemony between the novel The Adventures of Huckleberry Finn and The Kite Runner.}

In this discussion, the researcher will explain about the similarities of hegemony in the two novels. This hegemony becomes the main discussion because the two novels discuss the history of their social environment. The writer's awareness of social phenomena is presented in both two works. Hegemony is the domination of a dominant group over a subordinate. In this discussion of hegemony, the two writer describe social phenomena with their creative ideas. However, there is a relationship that influences the creation of literary works in the discussion of this hegemony.

\section{Religion as a Cultural Hegemony}

The first aspect that will be discussed is about the similarities in the novels The Adventures of Huckleberry Finn and The Kite Runner. Culture becomes an important part in explaining hegemony in these two novels. And the most important aspect is religion. In The Adventures of Huckleberry Finn, Huck Finn is a child who is taught about belief in God and the rules he must follow. In addition, Khaled Hosseini also portrays religion as a main factor of cultural hegemony in The Kite Runner. Through the main character Amir, is someone who also knows about religion and its rules through his teacher. Through this religious role, Huck Fin and Amir came to know that a person has principles in his life. But in practice, these two novels explain that religion is a tool for the domination of the dominant class. Slavery in America and the massacre of the Hazara in Afghanistan are caused by wrong religious interpretation among the social system. Religion is a system of rules that should be the basis of humanity. But in both novels, religion supports the domination which can emerge an inhumane systems and rules.

In the novel The Adventures of Huckleberry Finn, Huck Finn becomes the main character who must struggle in his consciousness and way of thinking. His decision to free Jim from slavery was in contrast to the Christian teachings he received. So he had to think of himself as a despicable and sinful Abolitionist. Likewise with Amir in the novel The Kite Runner, when he intend to free and adopt Sohrab, Hassan's son, people who take the Sunni Islam consider Amir an 
despicable person because he went from America to Afghanistan only to free Hazara who is a Shi'a Muslim.

In South American society, religious rules are very important to strengthen the superstructure in the social environment. And one of the things that maintain it is religion. In the novel The Adventures of Huckleberry Finn society is forbidden to steal other people's property. That is right, but the meant of "property" there is including slaves. So, this makes Huck Finn guilty because he has decided to help Jim when he meets Jim on Jackson Island. Whereas at the beginning of the story, it is stated that Jim is Miss Watson's slave. From here, it indicates that Jim is considered as a property byher. Meanwhile, Miss Watson is the one who educates Huck Finn to be a good and moral human being. So, Huck's decision violates the moral rule because Huck repays Miss Watson's kindness with a bad deed. As in the quote:

The more I studied about this the more my conscience went to grinding me, and the more wicked and low-down and ornery I got to feeling. And at last, when it hit me all of a sudden that there was the plain hand of Providence slapping me in the face and letting me know my wickedness was being watched all the time from up there in heaven, whilst I was stealing a poor old woman's nigger that hadn't ever done me no harm (Twain, p. 318).

From this quote, it shows that Huck Finn feels guilty because he has violated religious rules. This guilt then arises along the way. Huck often thinks that he should return Jim to his owner. But on the other hand, Huck also thinks that Jim should be free because he was mistreated by his master. So this caused a conflict in Jim's mind, and he almost wanted to return Jim to Miss Watson with a letter. But finally he was able to endure it all and freed Jim.

This cultural hegemony in form of religion can also be found in the novel The Kite Runner. In this novel, Khaled Hosseini shows that religion is a determinant of one social class. The Pashtuns who are the dominant group believe in Sunni Islam and the Hazaras as subordinates believe in Shia Islam. So here, religion is the separator between the two. Amir, one of the Pashtuns, thought that he could not be a Hassan's friend because he was part of the Hazara. This happens because of the cultural system of the people who are proud of Pashtuns, so that, other groups have different class in the social environment.

Pashtuns have honor in society because they are the majority in Afghanistan and Hazaras do not have that because they are a minority. This honor can be seen from Amir's luxurious life while Hassan is a poor person. In addition, history shows that Pashtuns are Sunni Muslims while the Hazaras are Shi'a Muslims. So that, the dominance of Sunni Islam over Shi'a continues in Amir and Hassan life. As in the following quote:

The book said part of the reason Pashtuns had oppressed the Hazaras was that Pashtuns were Sunni Muslims, while Hazaras were Shi'a. (Hosseini, p. 8)

Then it is strengthened by the following quote:

Never mind any of those things. Because history isn't easy to overcome. Neither is religion. In the end, I was a Pashtun and he was Hazara, I was Sunni and he was Shi'a, and nothing was ever going to change that. Nothing. (Hosseini, p. 22) 


\section{Racism and Racial Prejudice as an Ideological Hegemony}

Then, the second similarity in hegemony is in ideologi. This ideology is in the form of racial prejudice. In the novel The Adventures of Huckleberry Finn, racial prejudicism becomes the ideology of white people in South America. They assumed that every black person was a slave. Black people are often considered to commit bad deeds such as stealing. As in the following quote, where Pap thinks that freeing black people is a mistake because they will have a chance to steal:

Here's a govment that calls itself a govment, and let's on to be a govment, and thinks it is a govment, and yet's got to set stock-still for six whole months before it can take a hold of a prowling, thieving, infernal, white-shirted free nigger, and-“. (Twain, p. 50)

Furthermore, another quote shows that black people can be scapegoated in murder cases because society believe that black people are murderers. As in the following quote:

"Most everyone thought it at first. He'll never know how night he came to getting lynched. But before night they changed around and judged it was done by runaway nigger named Jim.” (Twain, p. 93)

This quote is taken from Huck Finn assasination mistery which left everyone confused. They assume that Huck's father was the one who killed him. But then, because Jim ran away when Huck Finn was killed, people changed their minds and thought that Jim had killed Huck Finn. Even though the public has not found any evidence to make Jim as a suspect.

In the novel The Kite Runner, Khaled Hosseini describes that Hazara are a not accepted by Pashtun society because they are trying to steal Pashtun dominance in Afghanistan itself. Beside that, they think that Hazara are not part of the original Afghanistan's society and even they are garbage. As in the following quote:

"Like pride in your people, your customs, your language. Afghanistan is like a beautiful mansion littered with garbage, and someone has to take out the garbage. (Hosseini, p. 249)

\section{Intellectual and Moral Leadership}

Then, the third is intellectual and moral leadership. Hegemony is an act of domination supported by the role of intellectual and moral leaders in society. Both of these novels portrays intellectual and moral roles both through school and parents. In the novel The Adventures of Huckleberry Finn, Huck Finn becomes an intellectual when he is under the care of Miss Watson and Widow Douglas. As in the following quote:

I had been to school most all the time and could spell and read and write just a little, and could say the multiplication table up to six times seven is thirty-five, and I don't reckon I could ever get any further than that if I was to live forever. (Twain, p. 32)

It is the same with Amir, as Pashtun, he has the opportunity to go to school, in contrast to Hassan. As in the following quote: 
When I was in fifth grade, we had a mullah who taught us about Islam. His name was Mullah Fatiullah Khan, a short, stubby man with a face full of acne scars and a gruff voice. He lectured us about the virtues of zakat and the duty of hadj; he taught us the intricacies of performing the five daily namaz prayers, and made us memorize verses from the Koran-and though he never translated the words for us, he did stress, sometimes with the help of a stripped willow branch, that we had to pronounce the Arabic words correctly so God would hear us better. (Hosseini, p. 14)

\section{Differences Hegemony between the novel The Adventures of Huckleberry Finn and The Kite Runner}

Besides the similarity, the researcher also find the differences of hegemony. This difference is portrayed on the background of state from two novels. Where the novel The Adventures of Huckleberry Finn portrays South American Society meanwhile The Kite Runner portrays about Afghanistan society.

State of South America and The Legality of Slavery

One of the main things that Mark Twain shows in the novel The Adventures of Huckleberry Finn is about slavery in South America. Slavery is considered legal and justified by society. The legality is described by Mark Twain through the documents that must be owned by an owner in order to get an ownership rights. As in the following quote:

Maybe you can get him to believe that Jim is your nigger-some idiots

don't require documents-leastways I've heard there's such down

South here. (Twain, p. 325)

This slavery was practiced by white Americans who had plantations for production to African-American ethnics. The physical characteristic of these people is having black skin. These black people were transported by the British colonies to America several hundred years before this novel was created. This slavery emerged in 1619 and referred to the "New World" in the history of slavery in the United States. At the time, British ships stopped in Virginia were carrying about 20 slaves to British colonial territory on the land of America. The slaves were then exchanged for food by local entrepreneurs who had settled in America (Nugraha, 2020).

Then, slavery became a normal thing in South America, especially for entrepreneurs or nobles who wanted workers with minimal wages. There were nobles or rich people who owned a lot of farmland and slaves, they were the Grangerford and Silas Phelps families. As in the quote showing slavery on the Grangerford estate

The old gentlemen owned a lot of farms and over a hundred niggers.

(Twain, p. 165)

Of course, as an aristocrat he had a lot of land and money. Therefore he had many slaves to work on his land. Even those slaves were distributed to their children, like Buck. The slave was worked to serve them. As in the following quote: "Each person had their own nigger to wait on them-Buck too" (Twain, p. 165).

Beside Grangerford family, there is also Silas Phelps who owns a cotton farm. As in the following quote: "Phelps' was one of these little one-horse cotton plantation, and they all look alike." (Twain, p. 326) 
On the Phelps estate, Huck describes the existence of slavery and the differences between the lives of white and black people. As in the following quote:

big double log-house for the white folks-hewed logs, with the chinks stopped up with mud or mortar, and these mud-stripes been whitewashed some time or another; round-log kitchen, with a big broad, open but roofed passage joining it to the house; log smokehouse back of the kitchen there little log nigger-cabbins in a row t'other side the smoke-house. (Twain, p. 327)

Then, the slaves were employed and not paid by them. And sometimes, the slaves get bad treatment from their owner. Of course, this creates class dominance in society which shows the supremacy of white people over other ethnic or race around them

\section{Taliban's domination in Afghanistan}

The Taliban domination in Afghanistan did not make things any better after conflicts happened in the previous years. Precisely with their presence in the leadership, they strengthen their power by practicing hegemony. The hegemony that is carried out is in the state order. In the concept of hegemony, the state includes two things, the first is civil society and the second is political society. On the other hand, civil society condition in Afghanistan is getting worse. Social problems such as poverty, sexual assaut, and murder happen again. In fact, the establishment of the Taliban was based on efforts to stop the conflicts and apply Islamic rules. But in reality, civil society often suffers, especially for the Hazaras.

The majority of Taliban is Pashtun. Therefore, they slowly strengthened their power through the killing of ethnic Hazara which is named as "ethnic cleansing". One quote shows: "And two years later, in 1998, they massacred the Hazaras in Mazar-i-Sharif." (Hosseini, p. 187)

Killing was done by Taliban soldiers, is a reflection of political society. Then, that act had frightened civil society. The practice of murder occurs everywhere and innocent people become victims. As Rahim Khan described it when he told Amir:

Alas the Afghanistan of our youth is long dead. Kindness is gone from the land and you cannot escape the killings. Always the killings. In Kabul, fear is everywhere, in the streets, in the stadium, in the markets, it is a part of our lives here, Amir agha. (Hosseini, p. 189)

Then, the political society is portrayed in Assef character. Since childhood, Assef was proud of Hitler and he wanted to be an influential person in Afghanistan. The reason Assef admire Hitler was because he could make Germany clear from Jews ethnic. In this context, he thinks that the Pashtuns should be able to control Afghanistan. Assef considers Afghanistan to be the land only for the Pashtuns and the Hazaras are just the group that pollutes Afghanistan. As in the following quote:

I am going to have a little chat with him, man to man, mard to mard. Tell him what I told my mother. About Hitler. Now, there was a leader. A great leader. A man with vision. I'll tell Daoud Khan to remember that if they had let Hitler finish what he had started, the world be a better place now. (Hosseini, p. 35) 
The quote ilustrates that since childhood, Assef had admired Hitler because he could lead and make his country better. Unlike in Afghanistan, which has experienced many conflicts as if there is not a leader.

And when Assef grew up, he decided to join Taliban. He made that decision because he wanted to revenge Hazaras. He considers that the pain he got when the communist invasion is a bad memory. Because, the invasion was supported by the Pharcami group, which was mostly ethnic Uzbek and Hazara. As in the following quote:

Every night the commandant, a half-Hazara, half-Uzbek thing who smelled like a rotting donkey, would have one of the prisoners dragged out of the cell and he'd beat him until sweat poured from his fat face. (Hosseini, p. 247)

The Pharcami is a socialist group trying to abolish the capitalists. It means, that group is trying to eliminate rich people who are mostly Pashtuns, such as the Assef family. Many Pashtuns were kidnapped and get jailed. Assef explains in a quote:

Not that it was a mystery; everyone knew the communist had no class. They came from poor families with no name. The same dogs who weren't fit to lick my shoes before the Shorawi came were now ordering me at gunpoint, Parchami flag on their lapels, making their little point about the fall of bourgeoisie and acting like they were the ones with class. It was happening all over: Round up the rich, throw them in jail, make an example for the comrades. (Hosseini, p. 247)

That is a portrayal of Afghanistan when it was ruled by the Communists in 1980s. To prevent this, Assef as a Taliban soldier thought that they were garbage that made the land of Afghanistan dirty. For that reason, whoever Pashtun who feels he was born in Afghanistan must defend his country from these criminals. As in the following quote:

"Like pride in your people, your customs, your language. Afghanistan is like a beautiful mansion littered with garbage, and someone has to take out the garbage. (Hosseini, p. 249)

\section{Similarities Struggle between the novel The Adventures of Huckleberry Finn and The Kite Runner}

Counter hegemony is an effort to resist the hegemony of the dominant class. From these two novels, the writers show their ideas to resist hegemony in social evironment. The main character of two novels, Huck and Amir struggle for their social change in their environment. In this case, Huck struggle to save Jim from slavery and Amir try to save Hassan's family from violence. So, there are two kinds of counter hegemony that are similar between one to another novel.

\section{Passive Resistance}

In the first novel, Huck Finn rescues Jim into free state. This was done, because Huck don't want Jim to get inhumane treatment from the owner. The resistance was done by escaping on a raft floating down the Mississippi River. In this adventure, Huck and Jim gain freedom through life on a raft. Even though Jim was arrested again at Phelps' farm, Huck was able to save Jim again until he was finally free. So through this event, Mark Twain only shows passive resistance from Huck 
Finn and Jim because both of them don't want to hurt themselves from the domination of Huck's guardians and Jim's owner. As in the following quote:

I laid there in the grass and the cool shade thinking about things, and feeling rested and ruther comfortable and satisfied. (Twain, p. 64)

This is similar to novel The Kite Runner. What Amir did to Hassan in flying a kite is a passive counter hegemony. In this kite fighting culture, Amir and Hassan can play together regardless of ethnicity or religion issue. Because after Afghanistan was controlled by the Taliban, the kite culture was abolished because it was not in appropriated with Islamic culture. But it is a way of Taliban to maintain its power through Islamic law. As in the following quote:

I had never seen so many people on our street. Kids were flinging snowballs, squabbling, chasing one another, giggling. Kite fighters were huddling with their spool holders, making lastminute preparations. From adjacent streets, I could hear laughter and chatter. Already, rooftops were jammed with spectators reclining in lawn chairs, hot tea steaming from thermoses, and the music of Ahmad Zahir blaring from cassette players. The immensely popular Ahmad Zahir had revolutionized Afghan music and outraged the purists by adding electric guitars, drums, and horns to the traditional tabla and harmonium; on stage or at parties, he shirked the austere and nearly morose stance of older singers and actually smiled when he sang--sometimes even at women. (Hosseini, p. 53)

\section{Humanistic Resistance}

Humanistic resistance is also found on both two novels. The humanist resistance is in form of friendship between the people from different classs. In the first novel, Huck saves Jim because he feels sorry if Jim gets bad treatment from his owner. Besides, Huck thinks that Jim is a good and smart black person. This portrays that Huck disagrees with the South American view that black people are bad people. In addition, in his adventures with Jim, Huck once lost Jim. From that, Huck felt that he had lost someone precious. As in the following quote:

Jim was gone! I set up a shout-and then another-and then another one; and run this way and that in the woods, whooping and screeching; but it warn't no use-old Jim was gone. Then I set down I cried; I couldn't help it. (Twain, p. 315)

That Huck's intention to save Jim was genuine. He wanted to give Jim freedom because Huck knew how it felt when he was dominated by his guardians.

It is the same with the novel The Kite Runner where Amir wants to play with Hassan both when flying kite or making a good stories. From this event, Amir thought that Hassan, as Hazara, was a smart and talented child. On several occasions, Amir also often assumed that Hassan could show his loyalty. Because Hassan ever protect him from Assef. Amir and Hassan's friendship then continued when Hassan died. Because fter Amir knew that Hassan had died, he wanted to save his son, Sohrab. This save is based on Amir's guilt that he couldn't protect Hassan. Even though Amir knew that Sohrab was a Hazara and a Shi'a Muslim, he still helped him because he was the son of his old friend. After he got Sohrab from 
Assef, he intended to adopt him even though he knew that the Pashtun family did not accept descendants from other ethnicities. As in the following quote:

"I'm not coming home alone. I'm bringing a little boy with me." I paused. "I want us to adopt him." (Hosseini, p. 283)

Amir knows that Pasthun have a highest social status in society. Therefore, Pashtuns are not able to adopt children because they are afraid that the adopted child does not have Pashtun blood. As in the following quote:

Blood is powerful thing, backem, and when you adopt, you don't know

whose blood you're bringing into your house. (Hosseini, p. 164)

This is similar to Huck, when he decided to make Jim free. He wants Jim to be free from the social system that hurts black people. Because black people are used as property and used as trade. Just as Amir released Sohrab because he knew that he would be treated badly when he was in Afghanistan. One of the bad treatments was Sohrab was forced to be a servant and entertainer by Assef. This happens after Assef bought him from the orphanage.

\section{The Difference of Struggle between the novel The Adventures of Huckleberry Finn and The Kite Runner}

An active resistance toward hegemony is only found in the novel The Kite Runner when Amir fights Assef. Amir does an active resistance against Assef while trying to free Sohrab. From this event, Amir does not approve what Assef did when he made a Hazara like Sohrab a servant and entertainer. As a result of the resistance, Amir and Assef were seriously injured. In the end, Sohrab was able to get out because he was able to save himself with Amir when Assef was in pain. As in the following quote:

The slingshot made a thwiiiiit sound when Sohrab released the cup.

Then Assef was screaming. He put his hand where his left eye had been just a moment ago. Blood oozed between his fingers. Blood and something else, something white and gel-like. That's called vitreous fluid, I thought with clarity. I've read that somewhere. Vitreous fluid. (Hosseini, p. 254)

\section{CONCLUSIONS}

This research aims to compare two literary works in the form of a novel. The theme of comparison is about struggle against hegemony from the dominant group described in the novel. This research uses the theory of comparative literature from Susan Basnett and hegemony theory from Antonio Gramsci. The two literary works are The Adventures of Huckleberry Finn by Mark Twain and The Kite Runner by Khaled Hosseini. Both literary works describes the hegemony and counter hegemony by the historical stories. Then, in these two works, the researcher finds similarities and differences in their literary works.

Those two novels can be compared because they have similarities. The similarities are in the element of hegemony, such as culture, ideology, and intellectual and moral leadership. Besides that, the similarities can be found on the struggle, such as passive and humanistic resistance. Meanwhile for the difference of hegemony, this research found that the state of two novels are different because 
in the novel The Kite Runner include physical hegemony through war and assasination. And the difference of struggle, this research find that The Kite Runner provide an active resistance toward a dominant group.

\section{REFERENCES}

Abrams, M. H. (1976). The Mirror and The Lamp: Romantic Theory and Critical Tradition. London-Oxford New York: Oxford University Press.

Azizah, F. N. (2019). The Lexical Relation in Surah Ar-Rahman in The Holy Qur'an Translation by Muhammad Mukhsin Khan and Muhammad Taqi-ud-Din AlHilali. Unpublished Graduate Thesis. Bandung: English Study Program, State Islamic University of Sunan Gunung Djati Bandung.

Britannica, T. E. (2019, August 30). Adventure of Huckleberry Finn. Retrieved from Encyclopaedia Britannica:

https://www.britannica.com/topic/Adventures-of-Huckleberry-Finn-novelby-Twain

Creswell, J. W. (2014). Research Design: Qualitative, Quantitative, and Mixed Methods Approaches (4th ed.). California: SAGE publication, Inc.

Hendarto, H. (1993). "Mengenai Konsep Hegemoni Gramsci", dalam Diskursus Kemasyarakatan dan Kemanusiaan. Jakarta: Gramedia.

Hosseini, K. (2007). The Kite Runner. London: Bloomsbury Publishing.

Nugraha, J. (2020, December 18). Sejarah 18 Desember: Penghapusan Perbudakan di Amerika Serikat. Retrieved from Merdeka.com: https://m.merdeka.com/jateng/sejarah-18-desember-penghapusanperbudakan-di-amerika-serikat-kln.html?page $=3$

Ratna, N. K. (2006). Teori, metode, dan teknik penelitian sastra. Yogyakarta: Pustaka Pelajar.

Suyitno. (2014). Kajian Novel dalam Spektroskop Feminisme dan Nilai Pendidikan. Yogyakarta: Graha Ilmu.

Twain, M. (2018). The Adventures of Huckleberry Finn. Jakarta: PT Gramedia Pustaka Utama.

Wiharjo, F. R. (2018). Bentuk-Bentuk Hegemoni dan Counter-Hegemoni Dalam Novel Entrok Karya Okky Madasari Perspektif Antonio Gramsci. Yogyakarta: Program Studi Sastra Indonesia Fakultas Sastra Universitas Sanata Dharma Yogyakarta.

Yusuf, M. (2017). Hegemoni Dalam Novel Bekisar Merah. Makassar: Universitas Negeri Makassar. 